\title{
Discovering Trends of Agricultural Drought in Tihama Plain, Yemen : A Preliminary Assessment
}

\author{
Ali Ahmed Dhaif Allah, Noorazuan Bin MD. Hashim, Azahan Bin Awang
}

Received:12 072016 / Accepted: 14102016 / Published online: 31 june 2016

(c) 2017 Faculty of Geography UGM and The Indonesian Geographers Association

\begin{abstract}
Agricultural drought is characterized by lack of sufficient moisture in the surface soil layers to support crop and forage growth. Indicators of agricultural drought often are precipitation, temperature and soil moisture to measure soil moisture and crop yield. This study aims to assess spatio-temporal variations of drought in the Tihama Plain, which is one of the most important agricultural areas in Yemen, which contributes about $42 \%$ of the total agricultural production in the country. In recent years, the Tihama Plain faced changes in the rainy season, which reflect negatively on agriculture production and water security in the area. In this study, the Standardized Precipitation Index (SPI) was used to temporally evaluate the situation of drought, also used Geographic Information Systems (GIS) in order to show the spatial variability distribution of drought in the study area. The analysis results of SPI-6 showed that the year of 1984, 1991, 2002, 2003, 2004, 2005, 2006 and 2008 were the most affected by drought during the study period of 30 years (1980-2010). It was also shown that 1991 was the worst years of drought experienced by the study area. Based on the fact that the study area is the most important agricultural areas in Yemen, it is recommended to study the drought and its impact on agricultural crops.
\end{abstract}

Keywords: Agricultural drought, drought indicators, GIS, Standardized Precipitation Index (SPI), Spatial distribution, Tihama Plain.

\begin{abstract}
Abstrak Kekeringan pertanian ditandai dengan kurangnya kelembaban yang cukup di lapisan tanah permukaan untuk mendukung pertumbuhan tanaman. Indikator kekeringan pertanian sering berupa presipitasi, suhu dan kelembaban tanah untuk mengukur kelembaban tanah dan hasil panen. Penelitian ini bertujuan untuk menilai variasi kekeringan spatio-temporal di Dataran Tihama, yang merupakan salah satu daerah pertanian terpenting di Yaman, yang menyumbang sekitar $42 \%$ dari total produksi pertanian di negara ini. Dalam beberapa tahun terakhir, Dataran Tihama menghadapi perubahan di musim hujan, yang mencerminkan negatif pada produksi pertanian dan keamanan air di daerah tersebut. Dalam penelitian ini, Indeks Pengendapan Standar (SPK) digunakan untuk mengevaluasi situasi kekeringan secara temporer, juga menggunakan Sistem Informasi Geografis (SIG) untuk menunjukkan distribusi variabilitas spasial kekeringan di wilayah studi. Hasil analisis SPI-6 menunjukkan bahwa tahun 1984, 1991, 2002, 2003, 2004, 2005, 2006 dan 2008 paling banyak terkena dampak kekeringan selama masa studi 30 tahun (1980-2010). Hal itu juga menunjukkan bahwa tahun 1991 adalah tahun-tahun terburuk kekeringan yang dialami daerah penelitian. Berdasarkan fakta bahwa wilayah studi adalah daerah pertanian terpenting di Yaman, disarankan untuk mempelajari kekeringan dan dampaknya pada tanaman pertanian.
\end{abstract}

Kata kunci: dataran Tihama. distribusi spasial, Kekeringan di pertanian, indeks presipitasi standar (SPI), GIS, indikator kekeringan,

\section{Introduction}

Drought has a major effect on cultivation in terms of the decrease in economic activity, agricultural productivity and drinking water stock in life-threatening cases, which has controlled the famine [Roy \& Hirway 2007].

Conceptually, a drought refers to a water shortage (the demand) relative to the supply [Dracup et al. 1980] that originates from the absence or reduction of precipitation due to atmospheric conditions. Droughts are commonly classified into meteorological, agricultural, hydrological and socioeconomic droughts

Ali Ahmed Dhaif Allah, Noorazuan Bin MD. Hashim and Azahan Bin Awang

School for Social, Development and Environmental Studies, Faculty of Social Sciences and Humanities, Universiti Kebangsaan Malaysia. Malaysia.

Correspondence email: azwan@ukm.edu.my
[AMS 2004]. Meteorological drought is a more common and natural event, whereas agricultural, hydrological and socioeconomic droughts emphasize more on human or social aspects [Eklund and Seaquist 2015].

The sequence begins with meteorological drought; persistent, dry conditions may induce agricultural, hydrological and water resources droughts (Andreadis et al. 2005; Vidal and Wade 2009]. Agricultural drought is characterized by the lack of sufficient moisture in the surface soil layers to support crop and forage growth (Vergni 2004). Indicators of agricultural drought often are precipitation, temperature and soil moisture to measure crop yield [Hayes et al. 2011].

Yemen is located in arid and semi-arid region, which makes it susceptible to many natural hazards. Over the past years. The country has suffered from climate-related hazards, which included extreme 
temperatures, floods, landslides, sea level rise, and droughts. While these hazards are a natural occurrence in Yemen, they nevertheless pose serious constraints on development and food security, and their intensity and frequency are likely to increase under a changing climate causing many problems such as decrease of groundwater, degradation soil and vegetation, unemployment, poverty and migration. Furthermore, it reduced agricultural production and food insecurity, making Yemen imports between $70 \%$ - 90\% of grains as well as imports a lot of other foodstuffs (Wiebelt et al. 2011). In addition, rainfall rates in Yemen is very low and the annual average ranges between $500-800 \mathrm{~mm}$ in high land, 40 - $100 \mathrm{~mm}$ in the coastal regions and 50 $\mathrm{mm}$ in the desert zones [Bruns and Taher 2009].

Over the last thirty years, Yemen and Tihama Plain experienced four periods of drought, 1979-1981, 19831984, 1990-1991, 2007-2009 [U.S. 1982; World Bank 1986; UNDESA/ESCWA 2013, Miyan 2015] causing a lot of damages on Yemeni economy, which largely relies on agricultural resources. According to the Ministry of Agriculture and Irrigation [2009], almost 73.5\% of the population lives in rural areas and works in the agricultural sector, and thus significantly depends on appropriate weather conditions to their livelihoods. According to ESCWA [2005], the 1990-1991 drought was the worst in the modern history of Yemen because this period of drought synchronized with the Gulf War in 1991, which forced nearly 800,000 Yemeni workers to return to Yemen. Hence, workers' remittances decreased, leading to economic growth retreat, and growing the inflation rate and foreign debt. The result of these negative effects was the decreased possibility of Yemen to cope drought and mitigation.

During that period of drought, agricultural production reduced severely, economic growth has been affected due to the low agricultural production contribution in the gross domestic product. For example, irrigated agriculture such as vegetables registered a decline in production by $16 \%$, as cereals yields dropped sharply, where production decreased for millet, sorghum and barley by $33 \%, 34 \%$, and $38 \%$ respectively. As for livestock, have witnessed a marked decrease by $11 \%$ as a result of the lack of pasture and forage due to drought [ESCWA 2005]. Meanwhile, about $43 \%$ of the population living below the poverty line, according to the estimates of 2009. This is expected to increase the number of hungry people in Yemen between 80,000 - 270,000 people by 2050 [Wiebelt et al. 2011], as a result of the severity of frequency of droughts and changing climate.

Moreover, the drought has become serious environmental problems faced by the study area, and has many negative effects on the region can be summarized in three groups. First, environmental impacts represented in the degradation of natural pastures and sand dune creeping, for instance, decreased pastures area from 10,132 hectares in 1993 , to $(1,519)$ hectares in 2009, a decrease of (74\%) [Tihama Development Authority 2010]. As for the sand dune area, it has increased from (218.336) hectares in 1993, to (319.784) hectares in 2008 and this increase in the dunes area has reduced the agricultural land [Al-Haddad 2008]. Second, economic effects such as reduced productivity in an area of major agricultural crops, and the decrease in the numbers of fruit trees (palm trees). Regarding the area, there was a decrease in the area planted for Levantine maize from $(3,696)$ hectares in 1985 to $(2,257)$ hectares in 2009 , a decrease of $(24 \%)$. For the productivity, the amount of production decreased from $(4,360)$ to $(3,484)$ tons, down by $11 \%$. In regards to the palm trees, their number dropped significantly from $(2,500,000)$ tree in 1998 to $(1,268,156)$ in 2011 and thus lost $1,231,844$ tree in 13 years, which represents a decrease of 33\% [Dhaifallah 2012]. Third, social effects was the low per capita income level, unemployment and migration of rural population to urban areas.

As noted above, it is clear that the study area suffers numerous social, environmental and economic problems. These problems come into existence as a result of the low of precipitation rates and frequent droughts. The study area has faced drought events that have occurred over the past years like other regions in Yemen. These problems are served as indicators which can be used to infer the occurrence of drought in the study area.

Many of the indicators were applied to quantify droughts by using meteorological data. Nevertheless, the most common and widely used at present is Standardized Precipitation Index (SPI) (Shah et al. 2015), which is one of the most reliable indicators to measure the duration, intensity and spatial extent of drought [McKee et al. 1995]. Calculation of the SPI is easier than some complex indicators such as Palmer Drought Severity Index (PDSI). This is because the SPI is based on precipitation data only, while index Palmer requires many parameters [Guttman 1998]. In addition, the SPI is not affected by geographical and topographical factors, therefore, it can be compared in both time and space [Lana et al. 2002].

SPI can track drought on multiple time scales, (i.e. $1,3,6,9,12,24$ and 48 months) and at the same time SPI is flexible with respect to the selected period space [McKee et al. 1993]. SPI 6 times scale is used to calculate agricultural drought based on the fact that, most of the agricultural systems respond to precipitation anomalies over a short period of time, usually $1-6$ months [WMO 2012].

By the fact that the study area is the most important agricultural areas in the country, which occupy $25 \%$ of the actual agricultural land tracts in Yemen, it ranked first in agricultural production, contribute $42 \%$ of the total agricultural production in Yemen [Ministry of Agriculture \& Irrigation 2009]. This study aims to assess spatiotemporal agricultural drought in Tihama Plain, using Standardized Precipitation Index (SPI), 
based on the rainfall data for the period of 1980-2010.

\section{The Methods}

The monthly rainfall data of five meteorological stations for the time period of 1980-2010 were acquired from the Public Authority of Agricultural Research, which covered the study area as shown in Figure1.

To determine the drought years, Standard Precipitation Index (SPI) was calculated using SPI calculator software obtained from the National Drought Mitigation Centre (NDMC) of the University of Nebraska, Lincoln using the following link:http://drought.unl.edu/MonitoringTools/ DownloadableSPIProgram.aspx.

The SPI was calculated using 6 months' time scale which is appropriate for the determination of drought. The formula for determining drought years as used in this research is:

Where is the formula?

$\mathrm{X}=$ Number of months in drought

Rainfall in the study area $=12$ month

Heavy Rainfall $=3$ month (July, August and September)

Normal dry $=12-3=9=$ No Drought

When $X=10$ or above $=$ Drought year

Explanation:

Usually, under normal circumstances Yemen Experience three months of heavy rainfall in July, August and September. Therefore, any year with a total of nine dry months is considered as a normal situation. On the other hand, any year with more than nine dry months is considered as a drought year. This means that, at least one months out of July, August or September did not receive sufficient rainfall as it used to be, thereby aggravating the drought condition already existing in the country.

After the drought years have been identified according to the method mentioned above, the results were transferred to ArcGIS 10.2 software in order to map the spatial distribution of the severity of drought in the study area.

SPSS 22 was used to compare the groups of study area. Therefore, the period was divided into six groups for each station. This includes [ 1980 to 1985,1986 to 1990, 1991 to 1995, 1996 to 2000, 2001 to 2005 and 2006 to 2010]. The Kruskal Wallis test was used to examine the differences between groups.

The results were then transferred to Excel spread sheet 2010, in order to calculate the frequency of drought, identify drought years and draw some graphs to explain the severity of drought.

Drought occurs when the SPI is negative on an on-going basis, and its severity up to -1.0 or less, and ending when the SPI becomes positive [McKee et al. 1993]. Therefore, each phenomenon of drought has a period to be determined by its beginning, end, and severity, in every month the drought continues (Table
1). Thus, the total positive SPI for all the months taken by drought might be called the "intensity" of drought [WMO 2012].

The SPI is calculated from the monthly precipitation record. The classification system proposed by McKee et al [1993] is used to determine the severity of drought (mild, moderate, severe and very severe) based to SPI value according to specific standards for any phenomenon of drought on any of time scales as shown in Table 2.

Table 1. Classification of drought based on the SPI index

\begin{tabular}{ll}
\hline SPI value & Classification \\
\hline 2.00 to more & Extreme Wet (EW) \\
1.50 to 1.99 & Very Wet (VW) \\
1.00 to 1.49 & Moderate Wet (MW) \\
0 to 0.99 & Mild Wet (MW) \\
0 to -0.99 & Mild Drought (MD) \\
-1 to -1.49 & Moderate Drought (MD) \\
-1.50 to -1.99 & Severe Drought (SD) \\
-2.00 or less & Extreme Drought (ED) \\
\hline Source: Ceglar et al.2008
\end{tabular}

Table 2. Classification of the SPI values and drought category

\begin{tabular}{ll}
\hline SPI value & Drought Category \\
\hline 0 to -0.99 & Mild Drought \\
-1 to -1.49 & Moderate Drought \\
-1.50 to -1.99 & Severe Drought \\
-2.00 or less & Extreme Drought \\
\hline
\end{tabular}

Source: McKee et al. 1993

There is a general consensus among users that using SPI on short time scales (3 and 6 months) describes the events of meteorological drought, as well as describes events of the drought affecting agricultural practices (agricultural drought), while the use over a long period of time scales (12 and 24 months) is more appropriate for monitoring hydrological drought and management of water resources [Raziei et al. 2009].

\section{Result and Discussion}

Through temporal analysis of drought using SPI 6, it is clear that there is variation in the severity of drought between meteorological stations under study, where the SPI values were less than -1 during the drought years. The temporal analysis results of drought for each station in the study area are shown below:

From 1980 to 2010, a total of 8 drought years were recorded in Zuhrah station. Analysis of the SPI time series indicate that, both the intensity and frequency of the drought increased progressively. For example, no drought was recorded between 1980 to 1985 and 
only one drought year each was recorded from 1986 to 1990 and from 1991 to 1995 . However, more frequent droughts were recorded from the 2003 to 2010, where 6 drought years were recorded in 2003, 2005, 2006, 2007, 2008 and 2009, with the year 2005 having the highest intensity of up to -3.08 SPI values (See Figure 2)

In Kalifah, a total of 6 drought years were recorded from 1980 to 2010. The first and the most extreme drought was recorded in the year 1991 with up to -4.34 SPI values. Another four years of successive droughts were recorded in 2002, 2003, 2004, 2005 and 2008. The drought in 2005 was also extreme and is the second in intensity after 1991, while the remaining years recorded severe droughts (Figure 3).
Jerbeh area recorded a total of 5 drought years between 1980 to 2010 . The droughts occurred in 1984, 1990, 1991, 2002 and 2004. The severity of the drought progressively increased with time from moderate droughts in 1984 and 1990 to extreme drought in 1991, 2002 and 2004. However, the 2002 drought is the most severe and extreme with the negative SPI values of -3.3, signifying an extreme drought condition. On the other hand, the 1990 drought is the mildest with the negative SPI values of -1.33 , signifying a moderate drought condition (Figure 4).

Bajil recorded the highest frequency of drought amongst the five station during the period under investigation. The area recorded a total of 10 drought

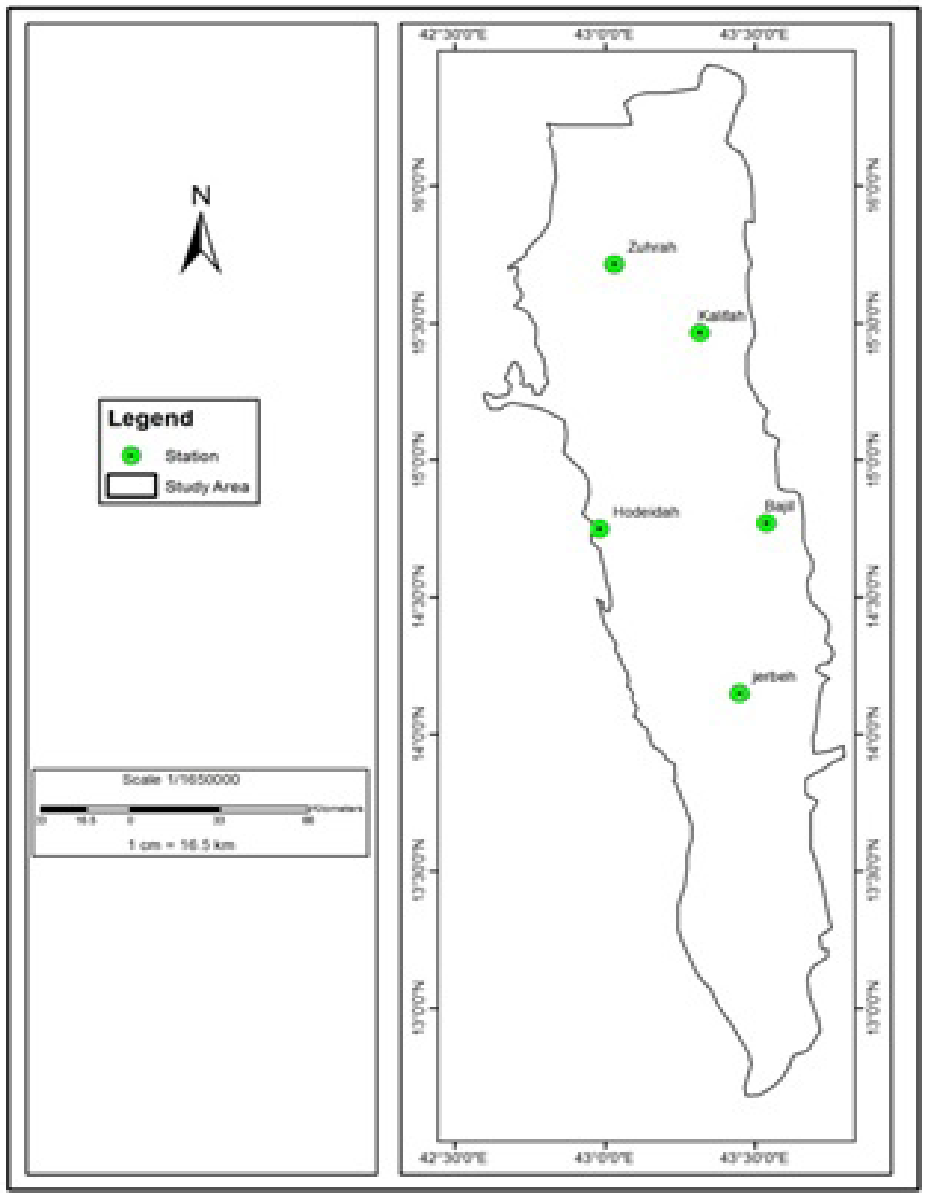

Figure 1. Distribution of meteorological stations in the study area

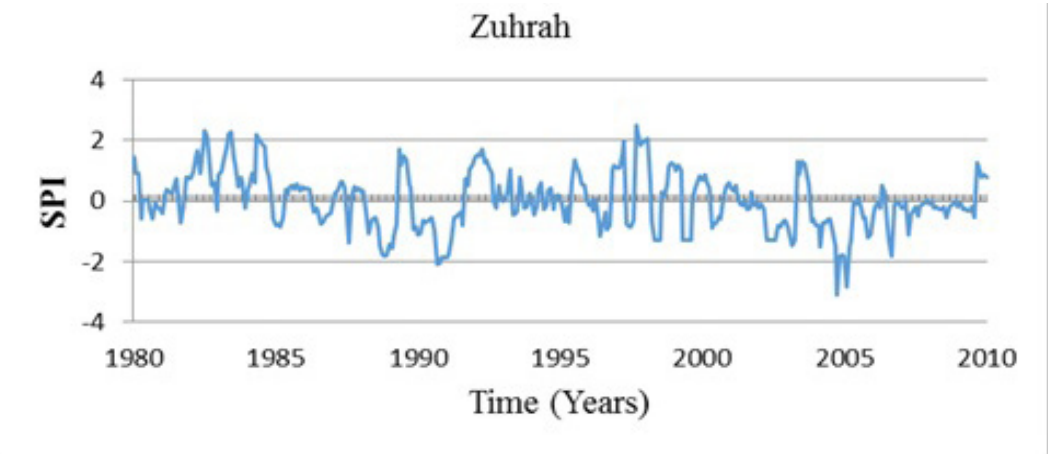

Figure 2. Drought Intensity Changes in Zuhrah Station 


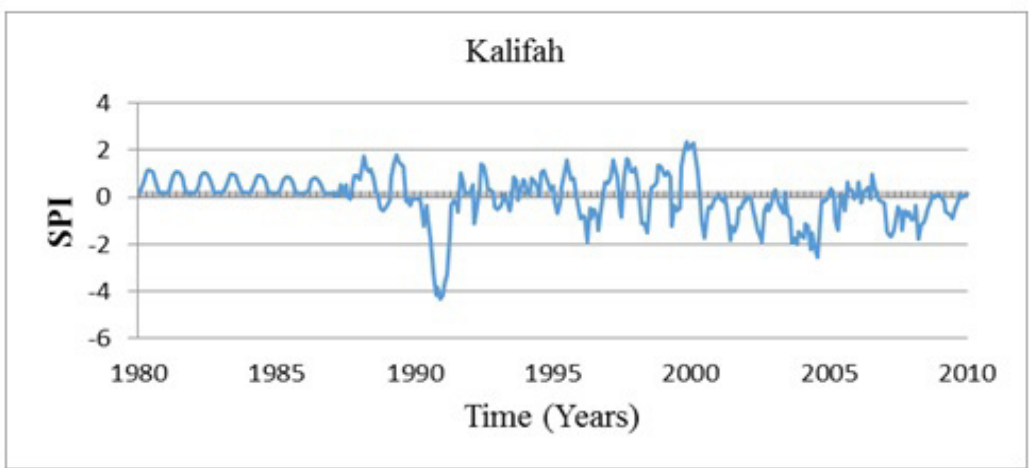

Figure 3. Drought Intensity Changes in Kalifah Station

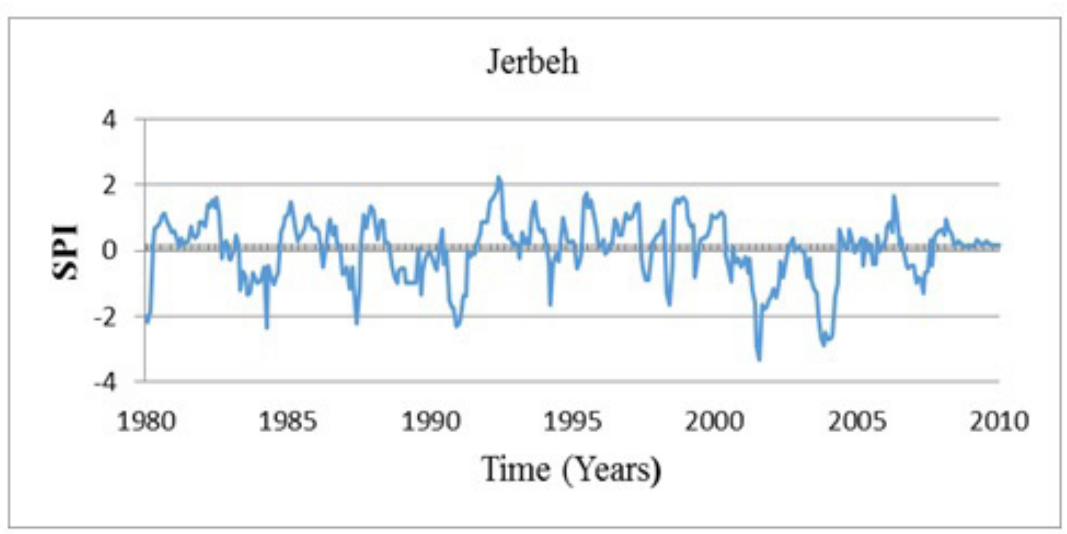

Figure 4.Drought Intensity Changes in Jerbeh Station

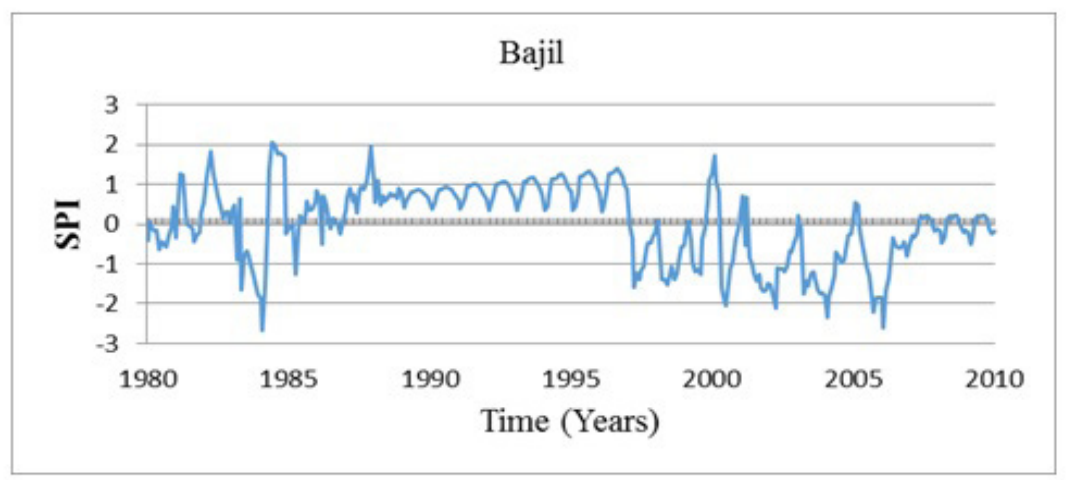

Figure 5. Drought Intensity Changes in Bajil Station

Table 3. Differences between stations in term of drought

\begin{tabular}{llllll}
\hline & Zuhra & kalifah & jerbeh & Bajil & Hodeida \\
\hline Chi-quare & 47.488 & 97.324 & 46.079 & 141.686 & 119.238 \\
df & 5 & 5 & 5 & 5 & 5 \\
Asymp. Sig. & .000 & .000 & .000 & .000 & .000 \\
\hline
\end{tabular}




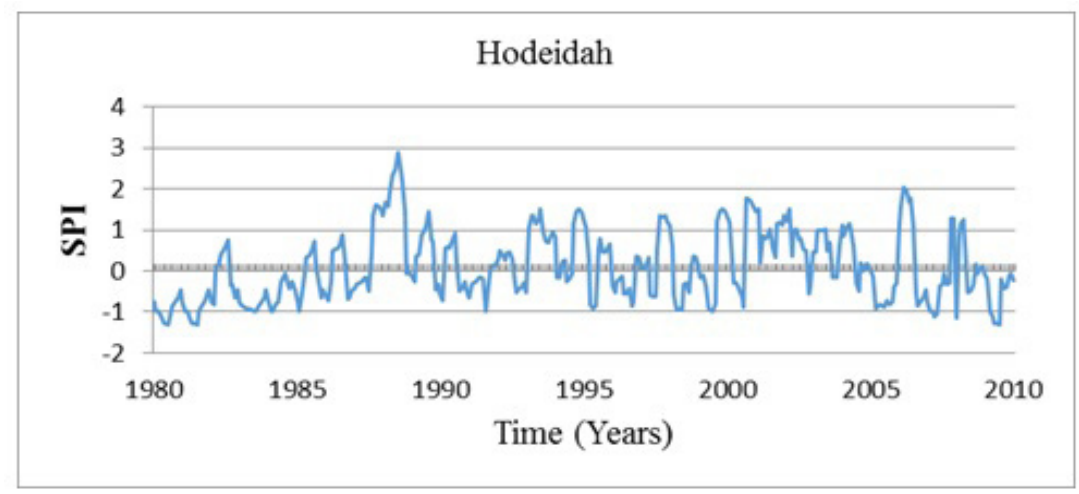

Figure 6. Drought Intensity Changes in Hodeidah Station

Table 4. Frequencies of drought categories based on the SPI classes

\begin{tabular}{llllllll}
\hline $\begin{array}{l}\text { Category } \\
\text { Stations }\end{array}$ & EW & VE & MW & NN & MD & SD & ED \\
\hline Zuhrah & 9 & 14 & 36 & 264 & 32 & 13 & 4 \\
Kalifah & 4 & 9 & 34 & 277 & 22 & 15 & 11 \\
Jerbeh & 2 & 14 & 35 & 267 & 26 & 11 & 17 \\
Bajil & 1 & 7 & 49 & 242 & 42 & 25 & 6 \\
Hodeidah & 5 & 14 & 48 & 291 & 14 & 0 & 0 \\
Total & 21 & 58 & 202 & 1341 & 136 & 64 & 38 \\
Percentage & $1 \%$ & $3 \%$ & $11 \%$ & $72 \%$ & $7 \%$ & $4 \%$ & $2 \%$ \\
\hline
\end{tabular}

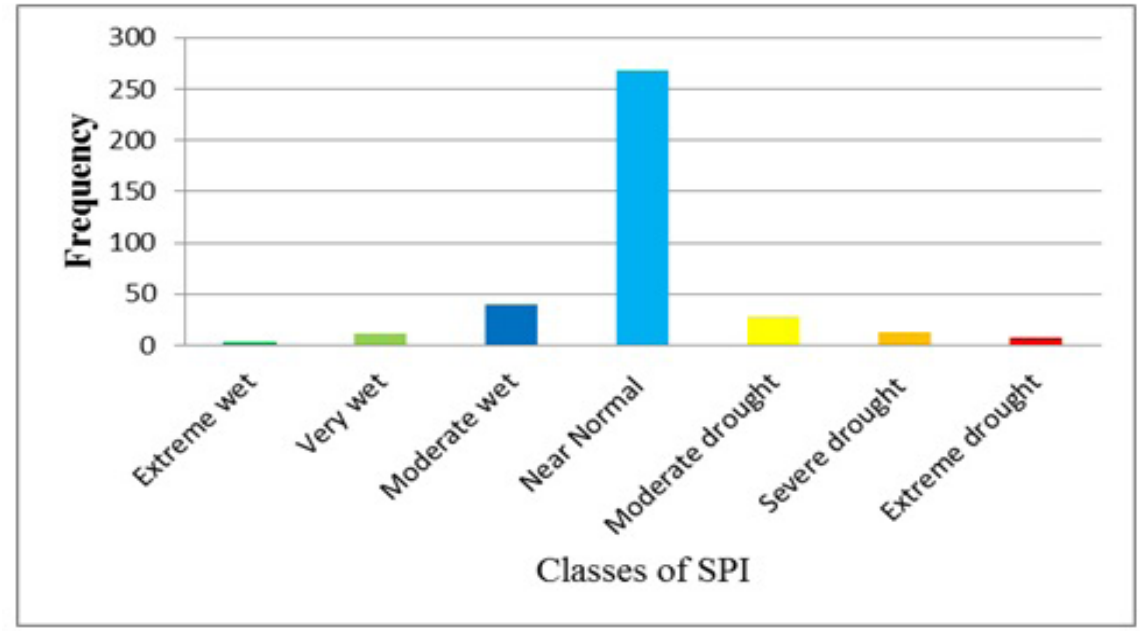

Figure 7. Frequency of mean annual of SPI classes 


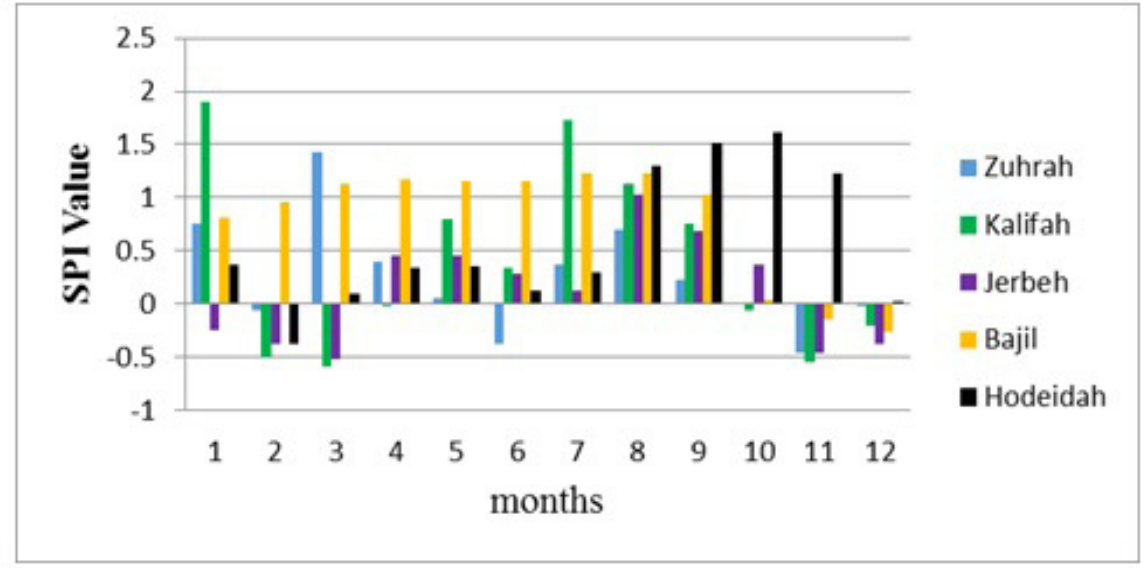

Figure 8. Distribution of SPI values for wet year 1995

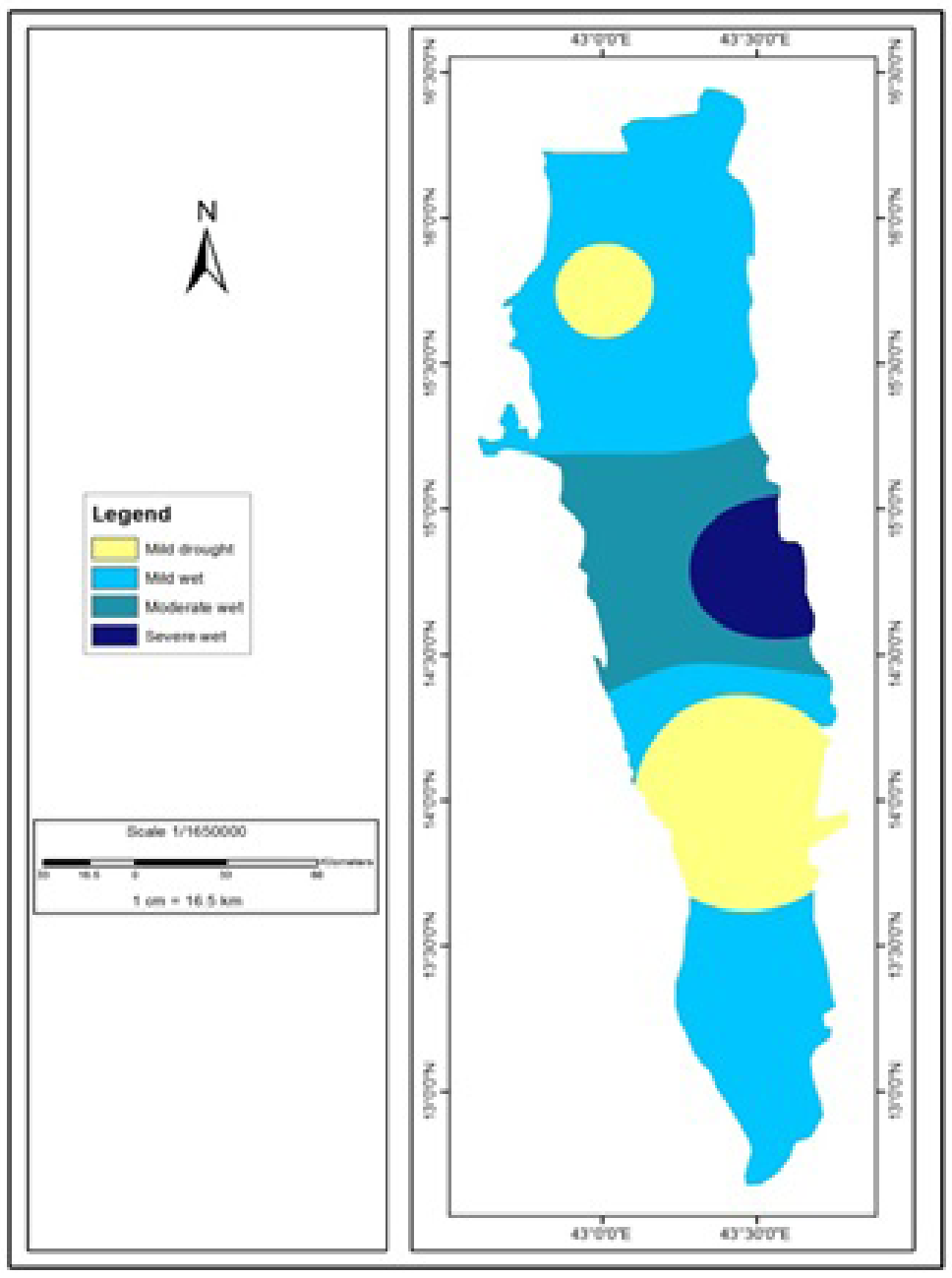

Figure 9. Spatial Distribution Map for wet year 1995 


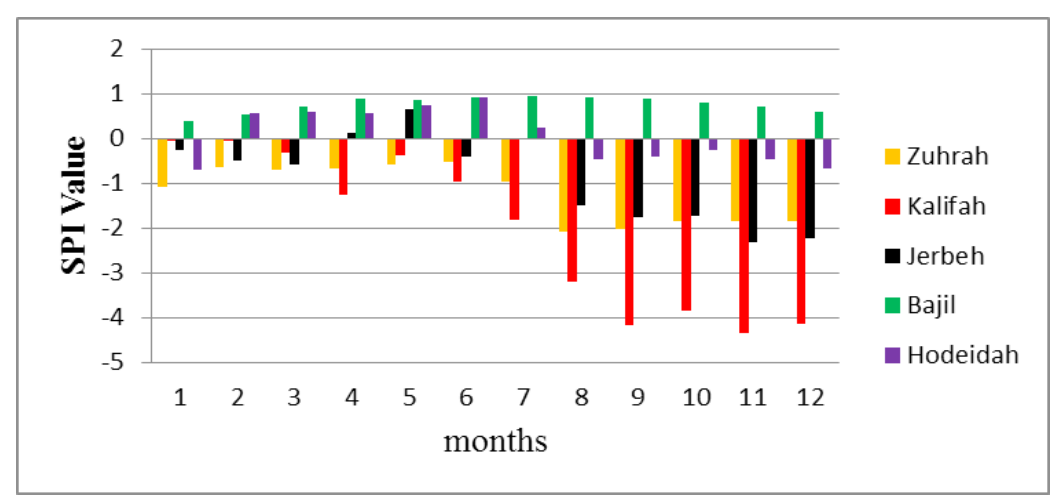

Figure 10. Distribution and intensity of drought in 1991

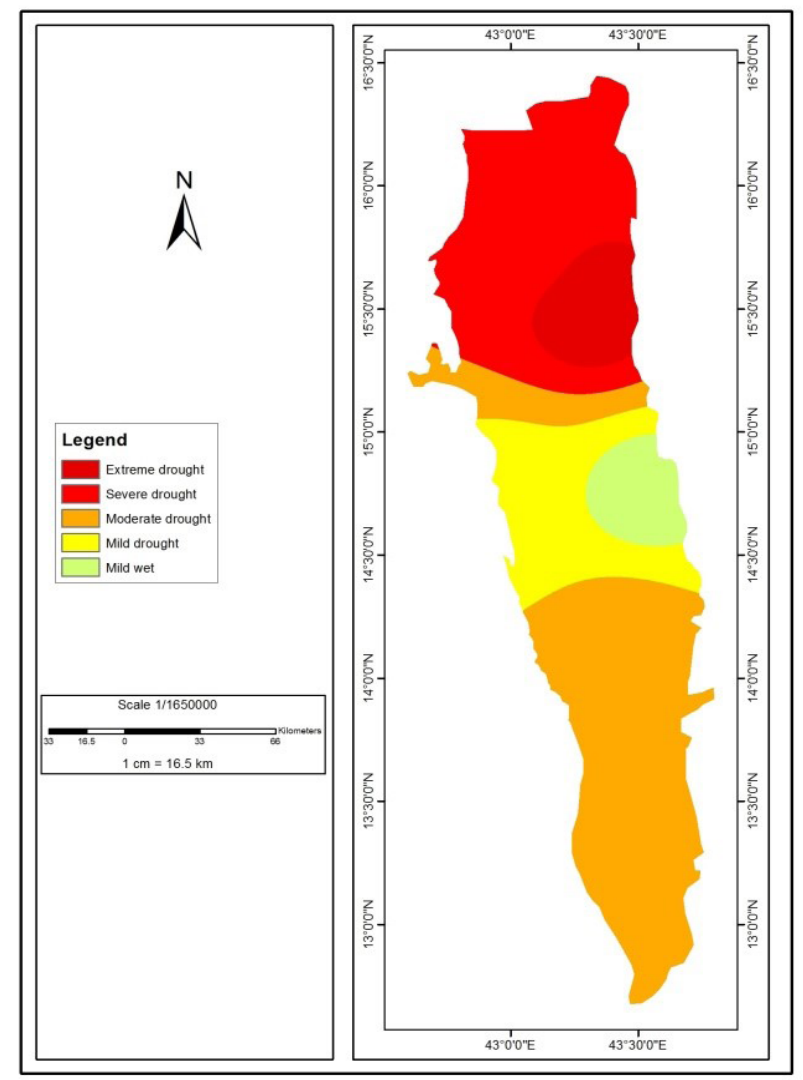

Figure 11. The distribution and severity of drought in 1991

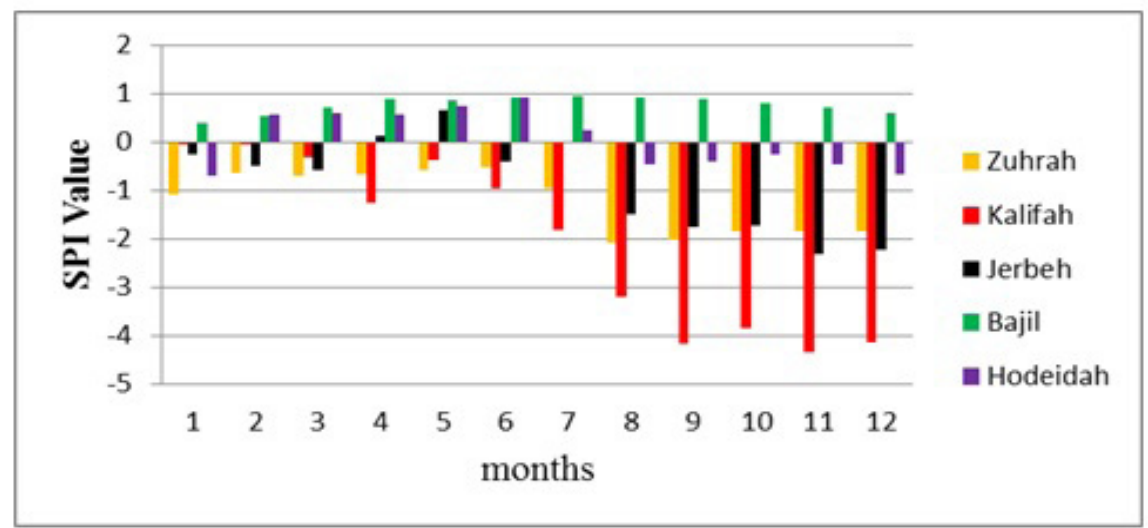

Figure 10. Distribution and intensity of drought in 1991 


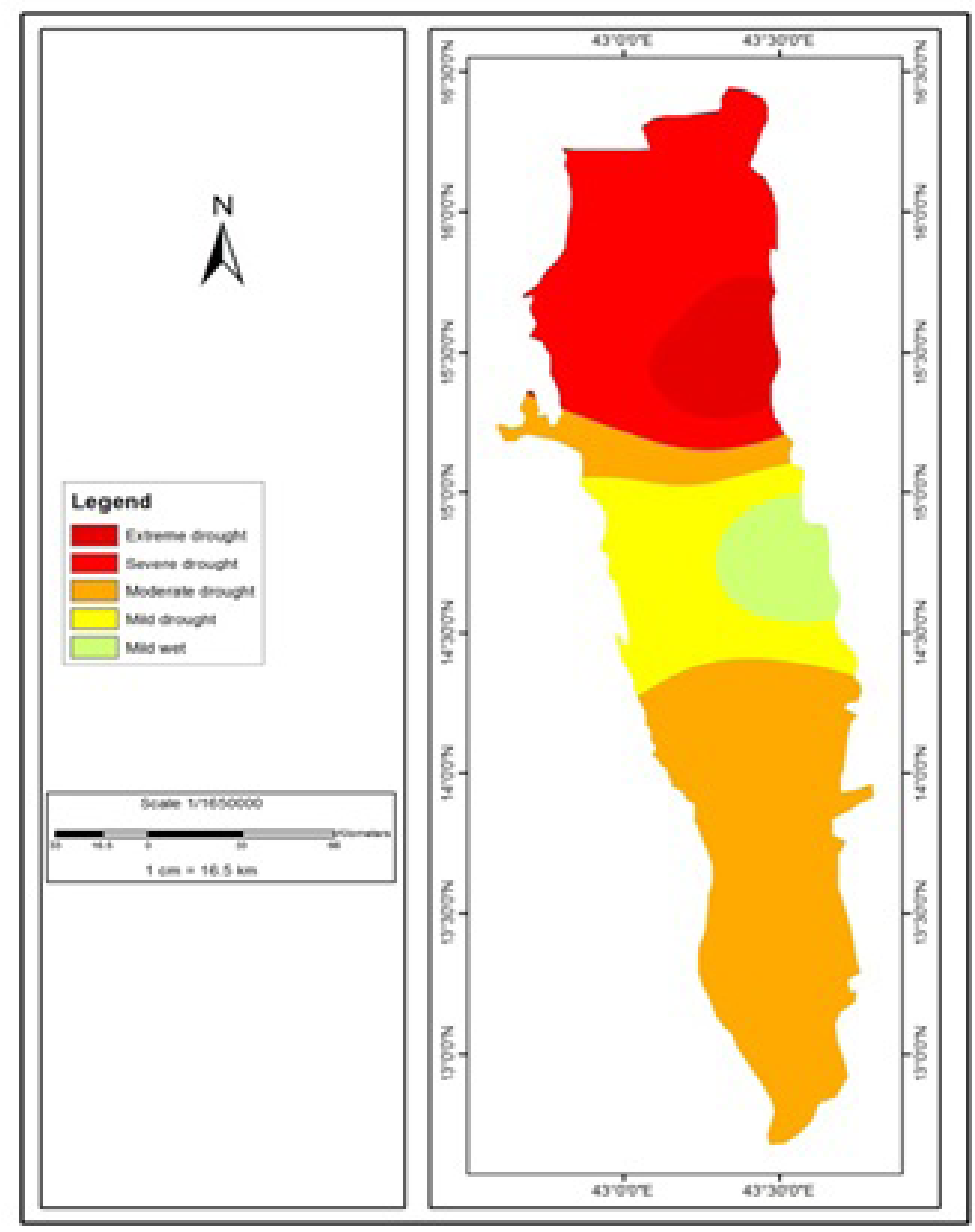

Figure 11.The distribution and severity of drought in 1991

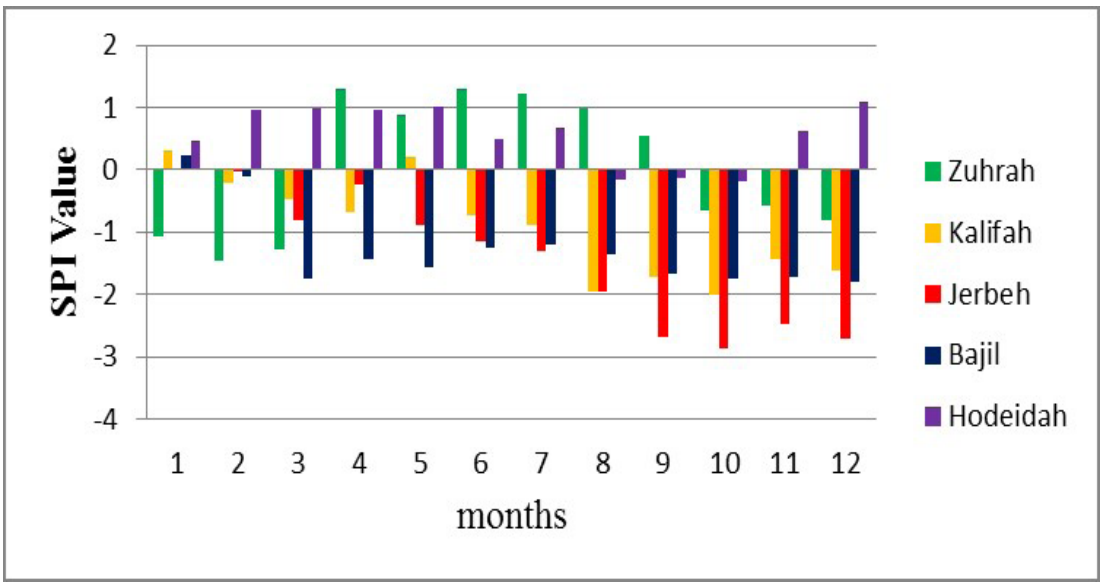

Figure 12. Distribution and intensity of drought in 2004 
years from 1980 to 2010 . However, the drought was more frequent and more severe between 2000 to 2010 , where 6 years of persistent droughts were recorded from 2002 up to 2007. Before this, droughts occurred intermittently in 1981, 1984, 1998 and 1999. The severity of the drought also increases with time from a milder drought in 1981 with SPI values of just -0.64 to a more extreme drought in 2007 with a negative SPI values of up to -2.61 , signifying an extreme drought condition (Figure 5).

In Hodeidah, there appears to be two separate drought regimes. In total 7 drought years were recorded during the study period. The first regime started from 1981 to 1985 after which, a period of normal rainfall resumes from 1986 until 2005. The second drought regime was recorded from 2006 to 2010 . However, the drought was not as intense as in the areas as only mild and moderate were recorded with the absence of severe drought. Moderate drought conditions with SPI values of -1.28 was recorded in 1981, 1982, 2008 and 2010 while the droughts in 1984, 1985 and 2006 were mild ones (See Figure 6).

Moreover, to make a confirmation on the results of the SPI 6 time scale, Kruskal Wallis Test to examine the differences between the five stations was performed. As shown in Table 3, the p values of all stations were $<$ 0.05 indicating that the drought was different between all stations. In another word, all stations showed there are statistically significant $(\mathrm{p}<0.05)$ variation or change in the drought intensity through the time period of the study.

The overall drought frequency in all the five stations indicate that on the average, near normal condition accounts for $72 \%$ in all the five stations put together for the 30 years' period of investigation. Moderate drought account for $7 \%$, severe drought $4 \%$ and extreme drought $2 \%$. The cumulative drought period for the stations accounts for $11 \%$. On the other hand, moderate wet for all the stations accounts for $11 \%$, very wet $3 \%$, and extreme wet $1 \%$. However, a more detailed examination of the result revealed that, out of the total of 1860 months observed in all the five stations, near normal condition is recorded 1341 times, moderate drought 136 times, severe droughts 64 times and extreme drought 38 times. On the other hand, extreme wet is recorded 21 times in all the five stations, very wet 58 times and moderate wet 202 times(see Table 4 and Figure 7).

The SPI 6, time scale was used for the determination of drought years, where the drought usually occurs when the SPI is negative, and its severity up to -1.0 or less, and ending when the SPI becomes positive. Accordingly, it has been shown by the results that there are spatial differences in the drought severity between meteorological stations in the study area during the drought years. It has been observed that the lowest SPI values occurred during the years 1991 and 2004, so these years were considered the worst drought years. On the other hand, the year 1995 was selected as a year of wet, where the most of SPI values were positive over all the stations.

The year 1995 appears to be unique throughout the study period. This is due to a radical amount of rainfall received in all the five stations under study as no drought is recorded in the year throughout the stations. During the year, two stations, the Kalifah and Hodeidah were severely wet with positive SPI values of 1.73 and 1.62 respectively, signifying a severe wet condition. The remaining three stations namely Zuhrah, Jerbeh and Bajile were moderately wet, each with positive SPI values of $1.43,1.03$ and 1.23 respectively, signifying a moderate wet condition (Figures 8 and Figure 9).

The year of 1991 recorded the worst drought in the last 30 years in the study area both in terms of distribution and intensity. During this year, Kalifah area recorded a drought intensity of up to -4.34 in the SPI value, which signifies extreme drought condition and the dryness persist for throughout the year (12 months). Zuhrah also recorded 12 month of dryness during the same year, but of lesser intensity ( -2.09 SPI values). Comparably, Jerbeh recorded a more intense drought than Zuhrah (-2.32 SPI values), but of relatively shorter duration as the drought last for 10 months of the year. The other two stations, Bajil and Hodeidah experienced a normal rainy year in 1991 (see Figure 10 and Figure 11).

In 2004, Jerbeh station which recorded normal rains in 2003, turns out to be extremely dry with 11 dry month and up to - 2.88 SPI values, signifying extreme drought situation. Again, Zuhrah station, which experienced drought in 2003, becomes moderately wet with positive SPI values of up to 1.31. During the same year, Kalifah recorded 10 dry months with up to -2.02 SPI values making it extremely dry and Bajil, 11 dry months with up to - 1.74 SPI values, signifying severe drought. Hodeidah remains relatively wet as in 2003 (See Figures 12 and Figure 13).

\section{Conclusion}

Through temporal analysis of drought using SPI 6 , it is clear that there are variations in the severity of drought between meteorological stations under study, which the SPI values were less than -1 during the drought years. Bajil station is the most affected by the drought with a total of 10 drought years from 1980 to 2010 , while Jerbeh station is the least affected with a total of 5 drought years. The analysis results by SPI 6 showed that the years 1984, 1991, 2002, 2003, 2004, 2005, 2006 and 2008 were the most affected by drought during the entire time period 30 years (1980-2010). The year 1991 recorded the worst drought throughout the study period, both in terms of distribution and intensity. During this year, Kalifah station recorded a drought intensity of up to -4.34 in the SPI value, which signifies extreme drought condition and the dryness persist throughout the year (12 months). Also, it turns out from the results that there are spatial differences in 
the drought severity between meteorological stations in the study area during the drought years. This can be identified through the SPI maps for the years of 1991 and 2004, which recorded the lowest SPI values compared to other drought years. Based on the fact that the study area is the most important agricultural areas in Yemen, it is recommended to study the drought and its impact on agricultural crops.

\section{References}

Al-Haddad.N.A. (2008). Geomorphological study of the phenomenon of sand dunes in the area of Zabid, (Master Thesis) Department of Geography, Sana'a University, Yemen.

AMS.(2004). Statement on meteorological drought. American Meteorological Society (AMS), Bulletin of the American Meteorological Society, 85, 771-773.

Andreadis, K. M., Clark, E. A., Wood, A. W., Hamlet, A. F., \& Lettenmaier, D. P. (2005). Twentieth-century drought in the conterminous United States. Journal of Hydrometeorology, 6(6), 985-1001.

Bruns, B., \& Taher, T. (2009). Yemen water user association study: findings and recommendations for a problemsolving approach. Groundwater and Soil Conservation Project, Sana'a, Yemen.

Ceglar, A., Zalika, C., \& Lucka, K. B. (2008). Analysis of meteorological drought in Slovenia with two drought indices. Balwois, Ohrid.

Dhaifallah, A.A. (2012). Spatial Variation of desertification in Hudeidah Governorate (Master Thesis) Department of Geography, Thamar University, Yemen.

Dracup, J., K. Lee, \& E. Paulson Jr. (1980). On the Definition of Droughts. Water Resources Research, 16(2), 297-302.

Eklund, L., \& Seaquist, J. (2015). Meteorological, agricultural and socioeconomic drought in the Duhok Governorate, Iraqi Kurdistan. Natural Hazards, 76 (1), 421-441.

ESCWA. (2005). Water Development Report 1: Vulnerability of the Region to Socio-Economic Drought. New York: United Nation. Available at:

http://www.escwa.un.org/information/publications/edit/ upload/sdpd-05-9-e.pdf

Guttman, N.B.(1998). Comparing the Palmer drought index and the standardized precipitation index. Journal of the American Water Resources Association, 34, 113-121.

Hayes, M., Svoboda, M., Wall, N., \& Widhalm, M. (2011). The Lincoln declaration on drought indices: universal meteorological drought index recommended. Bulletin of the American Meteorological Society, 92(4), 485-488.

Lana, X., Serra, C., \& Burgueno, A. (2002.) Patterns of monthly rainfall shortage and excess in terms of the standardized precipitation index for Catalonia. International Journal of Climatology. 21, 1669-1691.

McKee, T. B., Doesken, N. J. \& Kleist, J. (1993). The relationship of drought frequency and duration to time scales. In Proceedings of the 8th Conference on Applied Climatology (Vol. 17, No. 22, pp. 179-183). Boston, MA, USA: American Meteorological Society.

McKee, T.B., Doesken, N.J., \& Kleist, J. (1995). Drought monitoring with multiple time scales. In: Proceedings of the Ninth Conference on Applied Climatology. American Meteorological Society, pp. 233-236.

Ministry of Agriculture \& Irrigation, (2009). Yearbook Agricultural Census, Yemen. Available at: http://www. agriculture.gov.ye/?lng=english\&
Miyan, M. A. (2015). Droughts in Asian Least Developed Countries: Vulnerability and sustainability. Weather and Climate Extremes, 7, 8-23.

Raziei, T., Saghafian, B., Paulo, A.A., Pereira, L.S., \& Bordi, I. (2009). Spatial patterns and temporal variability of drought in Western Iran. Water Resources Management. 23, 439-455.

Roy, A. K., \& Hirway, I. (2007). Multiple impacts of droughts and assessment of drought policy in major drought prone states in India. Gujarat, India: Centre for Development Alternatives.

Shah, R., Bharadiya, N. \& Manekar, V. (2015). Drought Index Computation Using Standardized Precipitation Index (SPI) Method for Surat District, Gujarat. Aquatic Procedia, 4, 1243-1249.

Tihama Development Authority. (2010). Study land cover change in the Tihama plain, Hodeidah, Yemen.

UNDESA/ESCWA. (2013). Drought management planning in water-scarce and in-transitioning-settings countries in West Asia/North Africa. Beirut, Lebanon, 24-25 June 2013. Available at:

https://sustainabledevelopment.un.org/content/ documents/2156Drought_EGM_Working_Draft_ Background_Paper_21June13.pdf.

U.S. Agency for International Development \& Ministry of Agriculture of Yemen. (1982). Agricultural Sector Assessment in Yemen Arab Republic. Sana’a. Available at: http://pdf.usaid.gov/pdf_docs/pnaal964.pdf.

Vergni, L. (2004). Agricultural drought: indices, definition and analysis. The Basis of Civilization--water Science? (286), 246.

Vidal, J. P., \& Wade, S. (2009). A multimodal assessment of future climatological droughts in the United Kingdom. International Journal of Climatology, 29(14), 2056-2071.

Wiebelt, M., Breisinger, C., Ecker, O., Al-Riffai, P., Robertson, R., \& Thiele, R. (2011). Climate Change and Floods in Yemen.

WMO. (2012). Standardized Precipitation Index User Guide. (M. Svoboda, M. Hayes and D. Wood). (WMO-No. 1090), Geneva.

World Bank. (1986). The World Bank annual report 1986. Washington, D.C 20433. Available at: http://documents. worldbank.org/curated/en/1986/01/438415/worldbank-annual-report-1986. 